\title{
The implications of refuge requirements for Bt cotton in India on world cotton markets
}

\author{
Rohit Singla $^{1 \star}$, Phillip Johnson ${ }^{2}$ and Sukant Misra² \\ ${ }^{1}$ Department of Agricultural Economics, McGill University, Montreal, QC, Canada. \\ ${ }^{2}$ Department of Agricultural and Applied Economics, Texas Tech University, Lubbock, TX, U.S.A
}

Accepted 5 July, 2013

\begin{abstract}
The study evaluated the potential impacts of refuge requirements for Bt cotton in India on world cotton markets. The objective was accomplished by estimating regional cotton yield functions in the Indian fiber model, and connecting it with rest of the world fiber model. Results revealed that the refuge requirements have potential to impact world cotton markets; magnitudes of impacts are smaller, however. The world cotton trade would be lower, and the cotton prices would be higher under higher refuge requirements, and vice versa. As the refuge requirements for an insecticidal Bt technology depend on its replacement rate, the time spent in R\&D and regulation of the technology has implications for Bt crops refuge requirements and world commodity markets.
\end{abstract}

Key words: Bt cotton, India, refuge requirements, world cotton markets, world fiber model.

${ }^{*}$ Corresponding author. E-mail: rohit.singla@mcgill.ca. Tel: (514) 398-4400 (x 0212). Fax: 514-398-7990.

\section{INTRODUCTION}

A large number of studies reported that insect-resistant Bt crops (such as Bt cotton and Bt corn) have led to significant productivity gains, reductions in insecticide use, or both throughout the world. Some examples of these studies describing the farm-level impacts of $\mathrm{Bt}$ crops are: James (2009), Bennett et al. (2004, 2006), Purcell and Perlak (2004), Huang et al. (2002), Qaim (2003), Yorobe and Quicoy (2006), and Brookes and Barfoot (2007). Other than these farm-level studies, there are studies (Pekaric-Falak et al., 2001; Brookes et al., 2010; Frisvold and Reeves, 2007; Frisvold et al., 2006; Elbehri and Macdonald, 2004; Anderson et al., 2008; Falck Zepeda et al., 2000) that examined the trade, price and welfare effects of $\mathrm{Bt}$ crops adoption on world markets. These studies reported an increase in agricultural trade, a reduction in prices, and an increase in welfare of people all over the world after commercialization of Bt crops.

Despite the aforementioned positive impacts of $\mathrm{Bt}$ crops, one of the primary concerns in adopting Bt crops is the potential resistance by insects to the $\mathrm{Bt}$ toxin present in the Bt crop (Shelton et al., 2000). To address this concern, Environmental Protection Agency (EPA) established a mandate requiring $B t$ growers to grow a proportion of non-Bt refuge ${ }^{1}$ along with $\mathrm{Bt}$ crop. The mandate provides farmers choice of a sprayed refuge option and an unsprayed refuge option. With sprayed refuge option, growers may plant up to $80 \%$ of their total acres to $\mathrm{Bt}$ varieties and at least $20 \%$ to non-Bt varieties and they are allowed to use conventional pesticide throughout. With the non-sprayed option, producers may plant $95 \%$ of their acres to Bt varieties, and spray Bt acres as needed with conventional insecticides; however, no insecticide may be used on $5 \%$ of refuge acres.

There are some studies (Livingston et al., 2004; Qiao et al., 2009, 2010; Singla et al., 2012; Hurley et al., 2001) that challenged the efficiency of EPA's universal mandate

${ }^{1}$ Refuges allow susceptible pests to thrive so they can mate with resistant pests that survive in the Bt crop fields thus extending the efficacy of the insectresistant varieties. 
on refuge requirements for $\mathrm{Bt}$ cotton and $\mathrm{Bt}$ corn. These studies provided some evidences of sustainability of productivity effects of $\mathrm{Bt}$ crops under a scenario of potential resistance development by various pests to the Bt toxin. Livingston et al. (2004), Qiao et al. (2009, 2010), and Singla et al. (2012) examined the refuge requirements for Bt cotton in the U.S., China, and India, respectively, in a bio-economic modeling framework. Livingston et al. (2004) found optimal structured refuges of $16 \%{ }^{2}$ for eleven year planning horizon for the U.S. cotton. Qiao et al. $(2009,2010)$ findings supported a 'zero refuge' policy for Bt cotton in China. Singla et al. (2012) found optimal refuge requirements of 42,19 , and $0 \%$ for North, Central, and South India, respectively, for a 15year time horizon. Hurley et al. (2001) also examined Bt corn refuge requirements in the U.S. by employing a bioeconomic model; they recommended optimal refuge requirements between 20 and $40 \%$. All the refuge requirements discussed previously, however, were found sensitive to some biological parameters used in the model.

Frisvold and Reeves (2008) examined that any mandates on refuge requirements have potential to decrease the production and profitability of cotton in the short run because of lower yields of cotton planted in refuge area. Their study, however, was at micro level and did not estimate how a change in refuge requirements could potentially affect the global trade and prices. The current study contributes to the literature by estimating the impact of various refuge requirements for Bt cotton in India on world trade and prices. It is important to examine the impact of refuge requirements In India as it is one of the largest ${ }^{3}$ producers of cotton in the world, and changes in proportion of area under $\mathrm{Bt}$ and non-Bt cotton has potential to alter world cotton trade flows and prices. We are considering only the impact of change in refuge requirements in India because the governments of two other major cotton producing countries, that is, the U.S. and China have already announced zero refuge policies for $\mathrm{Bt}$ cotton. The zero-refuge requirement for $\mathrm{Bt}$ cotton China is based on the idea that the abundant non-Bt host plants of the target pest provide sufficient natural refuges to delay resistance in the pest (Qiao et al., 2010). In case of the U.S., the stacked $\mathrm{Bt}$ varieties have replaced a

\footnotetext{
${ }^{2}$ Optimal/efficient refuge requirements vary with the length of planning horizon, that is, number of years it would take for a new technology to replace an existing technology. Here, a refuge requirement of $16 \%$ is based on the assumption that a new technology (such as stacked varieties) would replace the existing single-gene Bt technology in 11 years. Lower refuge requirements will be required if a technology get replaced earlier, and vice-versa. EPA has announced zero structured refuge requirements for stacked $\mathrm{Bt}$ cotton varieties in the U.S. in 2007. Since then the adoption of stacked varieties increased. They cover $63 \%$ of total cotton area in 2012 (USDA, 2012).

${ }^{3}$ India accounted for about $23 \%$ of world cotton production from one-third of world's cotton acreage it possesses (USDA, 2009). Once upon a time a net importer of cotton, India is now the second largest exporter of cotton in the world after the U.S. (National Cotton Council, 2009; USDA, 2009). The introduction of Bt cotton in India in 2002-03 is considered as the primary reason of India's transition from a net importer to a leading exporter of cotton (James, 2009; Choudhary and Gaur, 2010).
}

significant portion of single-gene Bt varieties (USDA, 2012), and there is zero refuge requirements for stacked varieties (EPA, 2012). There is relatively a small portion of area left under single-gene Bt varieties, and it is likely to be replaced by stacked varieties in the near future. So, virtually, there are no refuge requirements for Bt cotton in China and the U.S. This article, therefore, evaluates trade and price impact of Bt cotton refuge requirements in India only.

There is no study that examined the potential impact of refuge requirements for $\mathrm{Bt}$ crops on world markets. However, there are many studies ${ }^{4}$ examining the trade, price and welfare effects of Bt crops adoption on world markets. The studies by (Falck Zepeda et al., 2000; Frisvold et al., 2006; Pekaric-Falak et al., 2001) examined the trade, price and welfare effects of Bt cotton using partial equilibrium model. Brookes et al.. (2010) used similar methods to examine the production and price impact of biotech corn, canola, and soybean crops. The studies conducted by Pekaric-Falak et al., (2001) and Frisvold and Reeves (2007), however, employed general equilibrium modeling framework to estimate the economy-wide impact of $\mathrm{Bt}$ cotton on trade, prices and welfare. Elbehri and Macdonald (2004) also used general equilibrium framework to examine the trade and price impact of Bt corn.

The current study examines the potential impact of various refuge requirements for $\mathrm{Bt}$ cotton in India on world cotton markets by estimating the regional cotton yield models in the Indian fiber model, and then connecting the Indian model to rest of the world fiber model. The specific objectives of this study are (1) to estimate the cotton yield models for the three cotton growing regions in India (2) to estimate and compare the trade and price impacts under status quo; under efficient Bt cotton refuge requirements in India for 10 - and 15years planning horizons; and the refuge requirements mandated by EPA.

\section{CONCEPTUAL MODEL}

The conceptual analysis presented here provides the expected directional change in the world fiber market, with a change in refuge requirements in India. It can be hypothesized that increased refuge requirements for $\mathrm{Bt}$ cotton varieties in India would decrease the world cotton supply because of lower yield of cotton planted in refuges. A decrease in world cotton supply could potentially increase world cotton prices, ceteris paribus. Given that the demand for cotton is rising rapidly in India after the elimination of import quotas under the Multi-

\footnotetext{
${ }^{4} \mathrm{Bt}$ adoption and refuges go hand in hand because of a presence of complementarity between them. An increase in area under Bt crops decreases refuge area and vice-versa. Methods used to examine the trade and price impact of $\mathrm{Bt}$ crops adoption can be used to examine the impact of planting refuges.
} 


\section{- Bt cotton yield Impact -ーー- Textile demand Impact Refuge Compliance Impact}

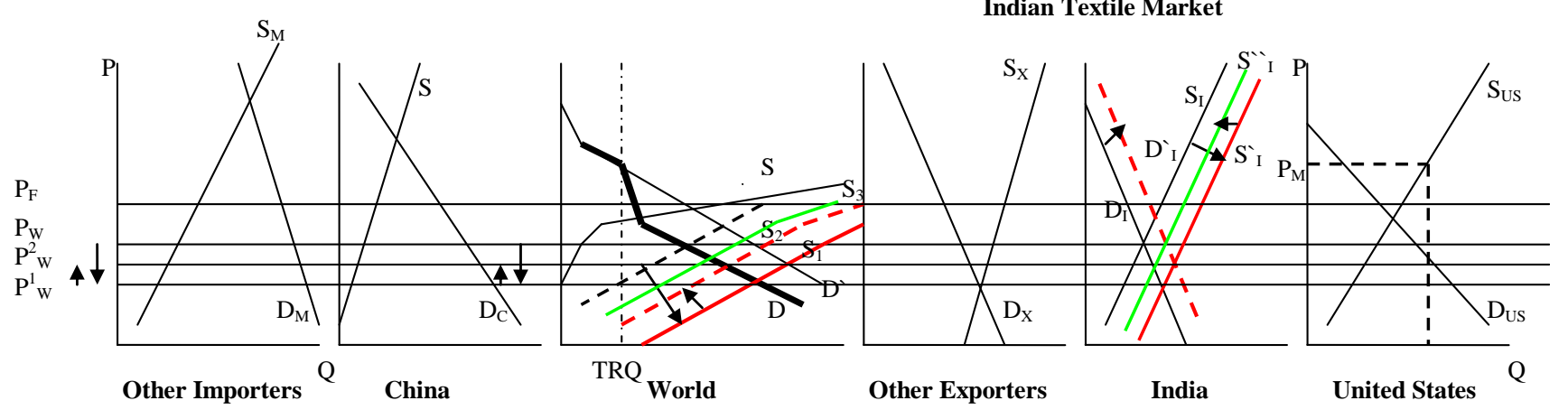

Figure 1. Impacts of refuge requirements on the U.S., India and world cotton markets

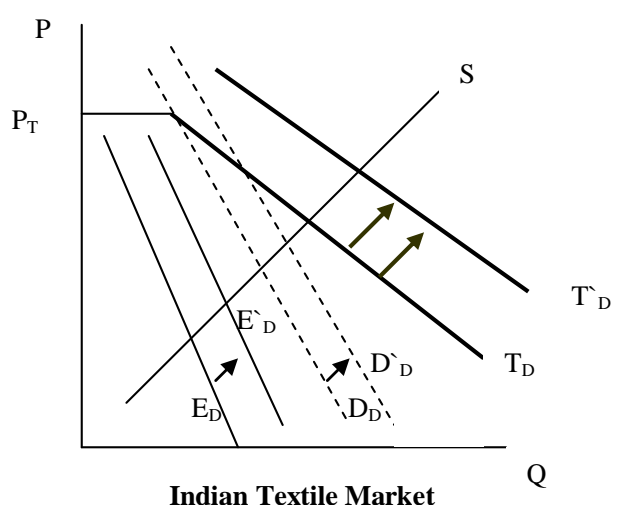

Fiber Arrangement (MFA) ${ }^{5}$, a decrease in supply could have implications for the future trade flows of cotton.

A partial equilibrium analysis of a hypothesized cotton trade scenario including India, the U.S., China and the rest of the world (ROW) cotton importing/exporting countries is presented in Figure 1. India and the U.S. are presented as net cotton-exporting countries, implying that domestic supply is greater than the domestic demand for cotton. China is assumed to be a net cotton-importing country.

The conceptual analysis shows that the world price is $P_{W}$ after considering the Chinese Tariff Rate Quota (TRQ) and the U.S. marketing loan program. The free trade price is shown as $P_{F}$. The conceptual model suggests that an increase in the supply of raw cotton in India (as a result of increased adoption of $\mathrm{Bt}$ cotton) would shift the supply curve from $S_{l}$ to $S_{1}{ }_{1}$, which would shift the excess supply curve upward in the world cotton market from $S$ to $S_{1}$. This should result in a decrease in world price from $P_{w}$ to $P_{w}^{1}$ and an increase in the quantity traded. It can be inferred that an increase in the world supply of cotton does not necessarily translate into sustained higher revenues/profits for adopters of $\mathrm{Bt}$ cotton as prices for cotton could fall worldwide (Bennett et al., 2004; Huang et al., 2002), provided there is not a concurrent increase in demand.

The rising domestic demand for textiles in India

${ }^{5}$ MFA governed the world trade in textiles and garments from 1974 to 2004 . MFA imposed quotas on the amount of textiles and garments developing countries could export to developed countries. It expired on 1 January 2005. because of an increased standard of living in recent years, coupled with increased exports of cotton-based textiles associated with the elimination of import quotas under the multi-fiber arrangement (MFA), could increase demand for domestic and imported cotton in India. This is represented by the total demand for textiles increasing from $T_{D}$ to $T_{D}$ in Figure 1. Due to this increase in demand for textiles, the derived demand for cotton in India is expected to increase from $D_{l}$ to $D^{\prime}$. This would result in a decrease of the excess supply in the world market from $S 1$ to $S 2$, and an increase in the price from $P^{1}$ to $P^{2}$, and a decrease in the quantity traded.

With an increase in refuge requirement, the supply of cotton is expected to decrease because of lower yield of cotton planted in refuges. In Figure 1, this is represented by a shift in the supply of cotton in the Indian market from $S^{\prime}$; to $S^{\prime \prime}$. A decrease in supply would shift the excess supply curve to the left to $S_{3}$, resulting in a world price between $P_{w}$ and $P^{2}$. Nevertheless, the net change in world price and trade is an empirical question and can only be determined by the various elasticities of demand and supply involved (Landes et al., 2005).

\section{METHODS}

The conceptual analysis suggested that the expected impact of increase in refuge requirements would be to alter cotton trade flows and increase world prices of cotton. The empirical model allows testing this hypothesis as well as the estimation of the magnitude of the change in price and trade flows. This is achieved by estimating regional cotton yield response models in the Indian fiber model 


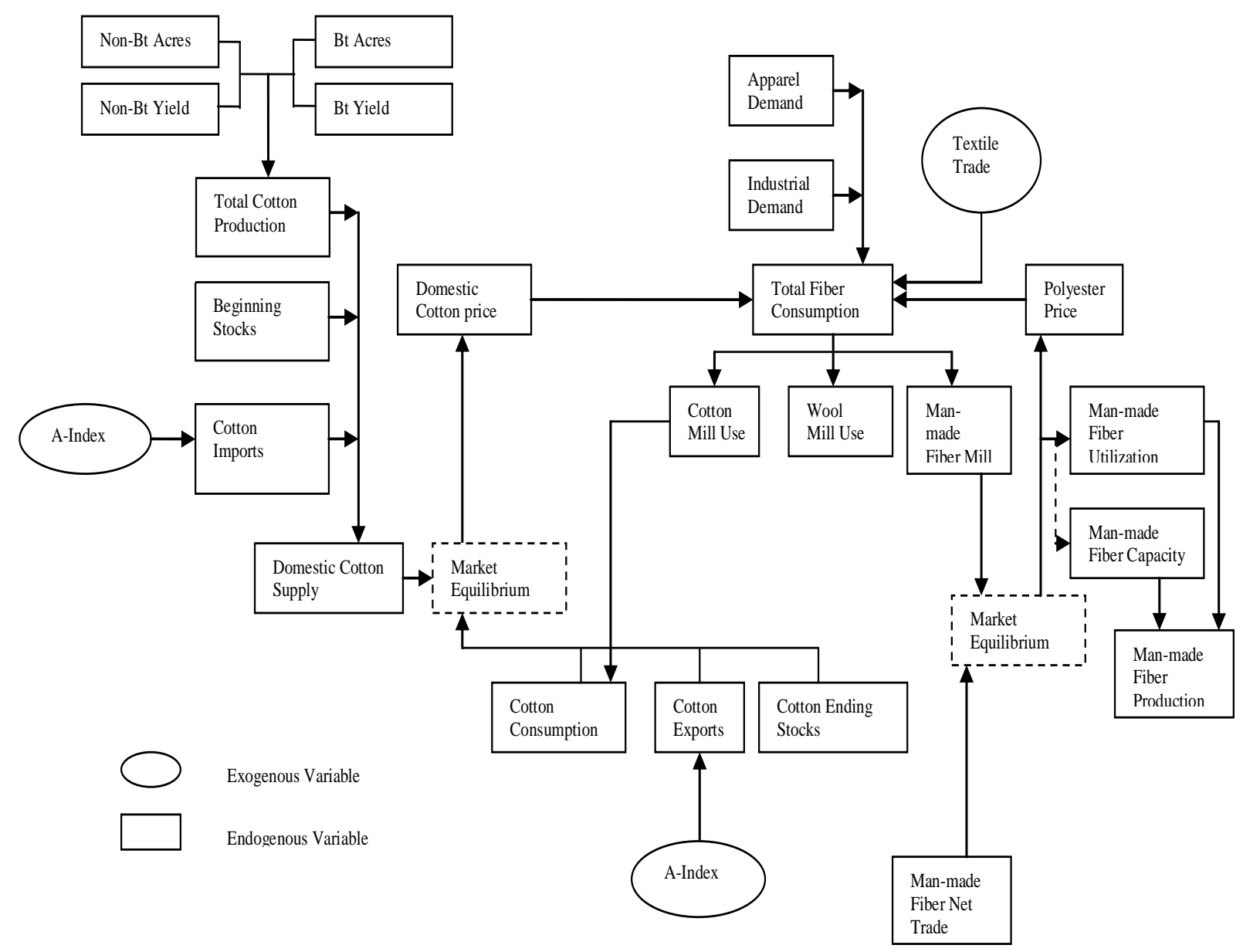

Figure 2. Indian fiber model.

component of the $\mathrm{WFM}^{6}$, where proportion of area under $\mathrm{Bt}$ varieties is considered among one of the exogenous factors. The calibrated Indian Fiber model is then connected to the WFM to simulate the potential impact of various refuge requirements on world cotton markets.

To estimate the cotton yield models, cotton area in India is first divided among three regions based on differences in agro-climatic conditions across regions (Chaudhary et al., 2008; Chaudhary, 2005). Then cotton yield models for the three regions in India were estimated as a function of proportion of $\mathrm{Bt}$ area after controlling for other regional factors. The cotton yield model for $j^{\text {th }}$ region can be specified as follows:

$$
Y_{j, t}=f\left(Y_{j, t-1}, q_{j, t}, F U_{j, t}, I r i_{j, t}, t\right)^{7}
$$

where $Y_{j, t}$ represents cotton yield in the $j^{\text {th }}$ region at time $t ; Y_{j, t-1}$ is lagged cotton yield in the $j^{\text {th }}$ region; $q_{j, t}$ is the proportion of refuge a farmer is growing in the $j^{\text {th }}$ region at time $t$; Irri $j_{j, t}$ is the area under irrigation for the $j^{\text {th }}$ region at time $t, F U_{j, t}$ is the fertilizer use in the $j^{\text {th }}$ region at time $t$; and $t$ is the time trend. The cotton yield models

\footnotetext{
${ }^{6}$ WFM is a partial equilibrium structural econometric model developed by Pan and Mohanty (2004). A brief description of the model along with data used is given in Appendix A. Two major applications of world fiber model are presented in Chaudhary et al (2008) and Pan et al (2007).

7 The regional time-series data (on cotton yield and other factors) used to estimate this model were obtained from Indiastat.com.
}

were used to estimate the $\mathrm{Bt}$ and non-Bt cotton yields that along with the respective acreages under $\mathrm{Bt}$ and non-Bt cotton determine cotton supply in the Indian fiber model as shown in Figure 2. As shown in the Figure, Bt and non-Bt cotton areas and yields contribute to total cotton production in India after accounting for beginning stocks and imports. The model also takes into account competition among fibers such as cotton, man-made fibers, and wool at the mill level.

The baseline projections for supply, demand, and prices of cotton, man-made fibers, and textiles in the Indian fiber market were generated under status quo conditions where the acreage under $\mathrm{Bt}$ cotton is expected to rise. The baseline projections assume the continuation of current policies such as China's TRQ and U.S. marketing loan program for cotton. The policy scenario projections were made by shocking the Indian Fiber model with efficient refuge requirements for $\mathrm{Bt}$ and non-Bt cotton for 15- and 10-years planning horizons as examined by Singla et al. (2012), and the refuge requirements mandated by EPA. The refuge requirements for a 15 -year planning horizon were $42 \%, 19 \%$ and $0 \%$ for North, Central and South India, respectively. The refuge requirements for a 10 -year planning horizon, however, were $29 \%$, $4 \%$ and $0 \%$ for North, Central and South India, respectively. The EPA refuge requirements used in the model were for those mandated for sprayed refuges, which is $20 \%$ for all the three cotton growing regions. Both baseline and policy scenario projections were developed for a 14-year time period beginning in 2012-2013 and ending in 2025-2026. The Indian Fiber model was connected 
Table 1. Regression estimates of regional cotton yield models in India.

\begin{tabular}{|c|c|c|c|}
\hline Independent variable & North & Central & South \\
\hline Intercept & $144.05(90.01)$ & $2212.54(1059.31)^{*}$ & $268.99(19.87)^{\star * *}$ \\
\hline$q_{j, t}$ & 249.67 (246.69) & $243.05(64.42)^{\star * \star}$ & $204.55(55.82)^{\star \star}$ \\
\hline$Y_{j, t-1}$ & $0.62(0.24)^{* *}$ & - & - \\
\hline$F U_{j, t}$ & - & $-6.52(3.11)^{\star}$ & - \\
\hline$I r r i_{j, t}$ & - & $-11439(5986.81)^{*}$ & - \\
\hline$F U_{j, t}{ }^{*} I r r i_{j, t}$ & - & $38.37(17.25)^{\star *}$ & - \\
\hline$t$ & - & - & $9.27(2.21)^{\star \star \star}$ \\
\hline$R^{2}$ & 0.54 & 0.89 & 0.86 \\
\hline DW statistic & 1.80 & 1.92 & 2.02 \\
\hline Number of observations & 18 & 18 & 18 \\
\hline
\end{tabular}

Figures in the parentheses are the standard errors. * ${ }^{* *}$ and ${ }^{* *}$ indicate significance at 10,5 and $1 \%$ levels, respectively.

to the World Fiber model to estimate the impacts on the world and the U.S. cotton markets. The policy effects were measured by comparing the differences between the policy scenario and baseline projections.

\section{RESULTS AND DISCUSSION}

The estimated coefficients of cotton yield equations for the three regions are presented in Table 1. The coefficient of proportion of area under Bt cotton $\left(q_{j, t}\right)$ represents the yield difference between $\mathrm{Bt}$ and non-Bt cotton; and it was found to be statistically significant in Central and South India after controlling for several factors such as fertilizers, irrigation, time trend and lagged yield. The $q_{j, t}$ was not statistically significant for North India due to lack of a sufficient number of observations for $\mathrm{Bt}$ cotton because of its late adoption. The coefficients of determination $\left(R^{2}\right)$ for the North, Central, and South regions were $0.54,0.89$ and 0.86 , respectively. A low value of $R^{2}$ in the North region may be due to erratic monsoon rainfall and high weather variability, which was not being captured by the model.

The estimated regression coefficients were used in estimating cotton production and supply in the Indian fiber model, which was further connected to WFM to develop baseline projections of the potential impacts on world cotton trade and prices assuming current trend in area under Bt cotton (and refuge). Also the baseline projections assumed a continuation of current policies including MFA quotas elimination and China's TRQ, which are based on World Trade Organization (WTO) commitments. The projections for fiber demand, supply and prices were developed for 14-year period under a set of assumptions for exogenous variables. After developing the baseline, three alternate scenario projections were developed for three different levels of refuge requirements. These include regional refuge requirements under 15-year planning period (Scenario 1), under 10-year ${ }^{8}$ planning period (Scenario 2), and those under EPA mandate (Scenario 3). Baseline and scenarios projections were made for India, the U.S., and world cotton markets as shown in Tables 2, 3 and 4, respectively. Average trade and price effects under the three scenarios are compared in Figures 3 and 4.

As shown in Table 2, average cotton yield in India would decline with an increase in refuge requirements for Bt cotton in India. Yield would decrease by an average of $1.89,0.86$ and $1.04 \%$, for refuge requirements under $15-$ year planning period, under 10 -year planning period, and under EPA mandate, respectively. Average reduction in cotton yield under 15-year refuge requirements was the highest followed by EPA and 10-year refuge requirements. Cotton yield reductions were found to be larger than cotton area expansions thus resulting into a decreased cotton production under the three refuge requirements scenarios. A decreased cotton production led to lower mill use, lower exports and lower ending stock on average. Negative impacts on mill use, exports and ending stock were highest under 15-year refuge requirements followed by EPA and 10-year refuge requirements. Impacts of various refuge requirements on the U.S. cotton market are reported in Table 3. Farm price of cotton in the U.S. would increase on average by $0.48 \%$ under 15 year refuge requirements, $0.18 \%$ under 10 -year refuge requirements, and $0.29 \%$ under refuge requirements mandated by EPA. Cotton production would also increase in the U.S. because of expectations of expansion and yield increments. Average mill use was almost unaffected under the three refuge requirements scenarios. Net cotton exports from the U.S. would rise on average because of a decrease in exports from India.

\footnotetext{
${ }^{8} \mathrm{~A}$ long term planning horizon assumes a longer period for a new technology to replace existing technology. A longer time in technology replacement corresponds to higher refuge requirements.
} 
Table 2. Estimated effects of efficient Bt cotton refuge policy compliance in India on Indian cotton market.

\begin{tabular}{|c|c|c|c|c|c|c|c|c|c|c|c|c|c|c|c|}
\hline Parameter & $2012 / 2013$ & $2013 / 2014$ & $2014 / 2015$ & $2015 / 2016$ & $2016 / 2017$ & $2017 / 2018$ & $2018 / 2019$ & $2019 / 2020$ & $2020 / 2021$ & $2021 / 2022$ & $2022 / 2023$ & $2023 / 2024$ & $2024 / 2025$ & $2025 / 2026$ & Avg. \\
\hline Area & & & & & & & & 000 Acres & & & & & & & \\
\hline Baseline & 29776.03 & 28559.67 & 28037.13 & 28836.89 & 29923.74 & 31544.69 & 31679.84 & 31836.54 & 31944.74 & 32266.15 & 32413.36 & 33769.29 & 33776.36 & 33907.84 & 31305.16 \\
\hline Scenario $1(\%)$ & 0.00 & 0.26 & 0.46 & 0.73 & 1.14 & 1.45 & 1.78 & 1.47 & 1.15 & 0.87 & 0.85 & 0.38 & 0.37 & -0.14 & 0.77 \\
\hline Scenario $2(\%)$ & 0.00 & 0.10 & 0.19 & 0.35 & 0.59 & 0.79 & 0.99 & 0.78 & 0.55 & 0.38 & 0.35 & 0.05 & 0.04 & -0.28 & 0.35 \\
\hline Scenario $3(\%)$ & 0.00 & 0.16 & 0.27 & 0.40 & 0.58 & 0.71 & 0.85 & 0.73 & 0.60 & 0.48 & 0.48 & 0.29 & 0.28 & 0.07 & 0.42 \\
\hline Yield & & & & & & & & Bales/Acres & & & & & & & \\
\hline Baseline & 0.94 & 0.99 & 1.01 & 1.02 & 1.02 & 1.02 & 1.03 & 1.05 & 1.07 & 1.11 & 1.11 & 1.13 & 1.14 & 1.15 & 1.06 \\
\hline Scenario 1 (\%) & -1.44 & -1.71 & -2.27 & -3.10 & -3.58 & -3.89 & -3.08 & -2.25 & -1.68 & -1.60 & -1.01 & -0.76 & -0.20 & 0.12 & -1.89 \\
\hline Scenario $2(\%)$ & -0.55 & -0.72 & -1.10 & -1.64 & -1.96 & -2.17 & -1.64 & -1.08 & -0.72 & -0.66 & -0.27 & -0.13 & 0.23 & 0.43 & -0.86 \\
\hline Scenario $3(\%)$ & -0.88 & -0.99 & -1.22 & -1.56 & -1.75 & -1.88 & -1.53 & -1.19 & -0.95 & -0.90 & -0.67 & -0.56 & -0.32 & -0.19 & -1.04 \\
\hline Production & & & & & & & & 000 Bales & & & & & & & \\
\hline Baseline & 28005.47 & 28344.79 & 28190.04 & 29305.40 & 30608.35 & 32159.23 & 32504.24 & 33569.34 & 34077.29 & 35846.54 & 36101.56 & 38069.63 & 38534.12 & 38854.32 & 33155.02 \\
\hline Scenario $1(\%)$ & -1.44 & -1.45 & -1.82 & -2.39 & -2.48 & -2.50 & -1.36 & -0.81 & -0.55 & -0.74 & -0.16 & -0.38 & 0.17 & -0.02 & -1.14 \\
\hline Scenario $2(\%)$ & -0.55 & -0.63 & -0.91 & -1.30 & -1.38 & -1.40 & -0.67 & -0.31 & -0.17 & -0.29 & 0.08 & -0.08 & 0.27 & 0.15 & -0.51 \\
\hline Scenario $3(\%)$ & -0.88 & -0.83 & -0.95 & -1.17 & -1.19 & -1.18 & -0.70 & -0.48 & -0.35 & -0.42 & -0.19 & -0.27 & -0.04 & -0.12 & -0.63 \\
\hline Mill Use & & & & & & & & 000 Bales & & & & & & & \\
\hline Baseline & 20835.15 & 21977.75 & 24313.19 & 25061.34 & 25276.15 & 25520.99 & 25556.29 & 26095.42 & 27046.58 & 28216.76 & 29422.71 & 30958.35 & 31644.92 & 32630.71 & 26754.02 \\
\hline Scenario $1(\%)$ & -0.14 & -0.12 & -0.14 & -0.19 & -0.19 & -0.18 & -0.04 & 0.01 & 0.02 & -0.02 & 0.06 & 0.01 & 0.10 & 0.04 & -0.06 \\
\hline Scenario $2(\%)$ & -0.05 & -0.05 & -0.07 & -0.11 & -0.11 & -0.11 & -0.01 & 0.02 & 0.02 & 0.00 & 0.05 & 0.01 & 0.07 & 0.03 & -0.02 \\
\hline Scenario $3(\%)$ & -0.08 & -0.07 & -0.07 & -0.09 & -0.09 & -0.08 & -0.02 & -0.01 & 0.00 & -0.01 & 0.02 & 0.00 & 0.04 & 0.01 & -0.03 \\
\hline Net Export & & & & & & & & 000 Bales & & & & & & & \\
\hline Baseline & 7217.60 & 6355.20 & 6326.55 & 6025.92 & 6687.38 & 7718.51 & 7844.53 & 8245.86 & 7724.98 & 8253.13 & 7256.56 & 7651.99 & 7414.95 & 6735.40 & 7247.04 \\
\hline Scenario $1(\%)$ & -4.58 & -5.72 & -7.52 & -10.73 & -10.70 & -9.90 & -5.85 & -3.54 & -2.63 & -3.17 & -1.22 & -1.92 & 0.37 & -0.28 & -4.81 \\
\hline Scenario $2(\%)$ & -1.76 & -2.44 & -3.69 & -5.76 & -5.90 & -5.54 & -2.95 & -1.44 & -0.89 & -1.25 & 0.10 & -0.43 & 1.06 & 0.72 & -2.15 \\
\hline Scenario $3(\%)$ & -2.81 & -3.30 & -3.98 & -5.30 & -5.15 & -4.69 & -2.98 & -2.02 & -1.61 & -1.82 & -1.10 & -1.33 & -0.40 & -0.74 & -2.66 \\
\hline End Stock & & & & & & & & 000 Bales & & & & & & & \\
\hline Baseline & 8504.68 & 8971.78 & 6978.06 & 5651.18 & 4749.24 & 4120.11 & 3672.39 & 3346.85 & 3095.87 & 2912.94 & 2772.52 & 2665.89 & 2570.14 & 2484.45 & 4464.01 \\
\hline Scenario 1 (\%) & -0.53 & -0.75 & -1.01 & -1.39 & -1.60 & -1.73 & -1.25 & -0.85 & -0.56 & -0.50 & -0.13 & -0.12 & 0.24 & 0.24 & -0.71 \\
\hline Scenario $2(\%)$ & -0.20 & -0.32 & -0.48 & -0.73 & -0.87 & -0.97 & -0.67 & -0.41 & -0.23 & -0.20 & 0.04 & 0.03 & 0.25 & 0.24 & -0.32 \\
\hline Scenario $3(\%)$ & -0.32 & -0.44 & -0.55 & -0.71 & -0.79 & -0.83 & -0.62 & -0.46 & -0.32 & -0.29 & -0.13 & -0.12 & 0.03 & 0.04 & -0.39 \\
\hline
\end{tabular}


Table 3. Estimated effects of efficient Bt cotton refuge policy compliance in India on the U.S. cotton market.

\begin{tabular}{|c|c|c|c|c|c|c|c|c|c|c|c|c|c|c|c|}
\hline Parameter & $2012 / 2013$ & $2013 / 2014$ & $2014 / 2015$ & $2015 / 2016$ & $2016 / 2017$ & $2017 / 2018$ & $2018 / 2019$ & $2019 / 2020$ & $2020 / 2021$ & $2021 / 2022$ & $2022 / 2023$ & $2023 / 2024$ & $2024 / 2025$ & $2025 / 2026$ & Avg. \\
\hline Farm price & & & & & & & & \$/Bale & & & & & & & \\
\hline Baseline & 75.23 & 74.53 & 75.89 & 77.20 & 78.02 & 78.61 & 78.80 & 79.09 & 79.93 & 79.92 & 81.01 & 82.67 & 85.08 & 85.63 & 79.40 \\
\hline Scenario $1(\%)$ & 2.34 & 1.50 & 1.77 & 2.49 & 2.07 & 1.78 & -0.85 & -0.94 & -0.70 & 0.14 & -1.29 & 0.02 & -1.44 & -0.17 & 0.48 \\
\hline Scenario $2(\%)$ & 0.90 & 0.69 & 1.00 & 1.47 & 1.24 & 1.08 & -0.62 & -0.73 & -0.49 & 0.01 & -0.90 & -0.03 & -0.96 & -0.13 & 0.18 \\
\hline Scenario $3(\%)$ & 1.43 & 0.83 & 0.84 & 1.12 & 0.91 & 0.77 & -0.32 & -0.33 & -0.28 & 0.09 & -0.48 & 0.04 & -0.57 & -0.05 & 0.29 \\
\hline Area & & & & & & & & 000 Acres & & & & & & & \\
\hline Baseline & 9725.79 & 9550.88 & 9686.34 & 9810.76 & 9886.45 & 9921.40 & 9987.91 & 10201.97 & 10240.74 & 10320.14 & 10384.52 & 10395.27 & 10480.64 & 10549.21 & 10081.57 \\
\hline Scenario $1(\%)$ & 0.00 & 0.31 & 0.20 & 0.24 & 0.34 & 0.29 & 0.25 & -0.10 & -0.12 & -0.09 & 0.02 & -0.16 & 0.00 & -0.19 & 0.07 \\
\hline Scenario $2(\%)$ & 0.00 & 0.12 & 0.09 & 0.13 & 0.20 & 0.17 & 0.15 & -0.08 & -0.10 & -0.07 & 0.00 & -0.11 & 0.00 & -0.13 & 0.03 \\
\hline Scenario $3(\%)$ & 0.00 & 0.19 & 0.11 & 0.11 & 0.15 & 0.13 & 0.11 & -0.04 & -0.04 & -0.04 & 0.02 & -0.06 & 0.01 & -0.08 & 0.04 \\
\hline Yield & & & & & & & & Bales/Acres & & & & & & & \\
\hline Baseline & 1.60 & 1.63 & 1.63 & 1.63 & 1.65 & 1.66 & 1.68 & 1.72 & 1.72 & 1.72 & 1.72 & 1.73 & 1.73 & 1.74 & 1.68 \\
\hline Scenario $1(\%)$ & 0.00 & -0.02 & 0.14 & 0.09 & 0.10 & 0.15 & 0.13 & 0.13 & -0.04 & -0.05 & -0.04 & 0.02 & -0.08 & 0.01 & 0.04 \\
\hline Scenario $2(\%)$ & 0.00 & -0.01 & 0.05 & 0.04 & 0.06 & 0.09 & 0.08 & 0.08 & -0.03 & -0.04 & -0.03 & 0.00 & -0.06 & 0.00 & 0.02 \\
\hline Scenario $3(\%)$ & 0.00 & -0.01 & 0.09 & 0.05 & 0.05 & 0.07 & 0.06 & 0.06 & -0.01 & -0.02 & -0.02 & 0.01 & -0.03 & 0.00 & 0.02 \\
\hline Production & & & & & & & & 000 Bales & & & & & & & \\
\hline Baseline & 15602.13 & 15576.02 & 15813.50 & 16009.82 & 16346.16 & 16471.85 & 16815.58 & 17497.11 & 17568.33 & 17732.89 & 17886.74 & 17954.09 & 18143.37 & 18313.88 & 16980.82 \\
\hline Scenario $1(\%)$ & 0.00 & 0.29 & 0.34 & 0.33 & 0.44 & 0.44 & 0.38 & 0.02 & -0.16 & -0.14 & -0.02 & -0.14 & -0.08 & -0.19 & 0.11 \\
\hline Scenario $2(\%)$ & 0.00 & 0.11 & 0.15 & 0.17 & 0.26 & 0.26 & 0.23 & 0.00 & -0.13 & -0.11 & -0.03 & -0.11 & -0.06 & -0.13 & 0.04 \\
\hline Scenario $3(\%)$ & 0.00 & 0.18 & 0.20 & 0.16 & 0.20 & 0.20 & 0.17 & 0.02 & -0.05 & -0.05 & 0.00 & -0.05 & -0.02 & -0.07 & 0.06 \\
\hline Mill Use & & & & & & & & 000 Bales & & & & & & & \\
\hline Baseline & 3640.43 & 3559.65 & 3486.49 & 3472.98 & 3386.03 & 3366.43 & 3284.86 & 3275.69 & 3048.80 & 2918.03 & 2812.47 & 2798.62 & 2763.08 & 2523.93 & 3166.96 \\
\hline Scenario 1 (\%) & 0.01 & 0.02 & 0.02 & 0.03 & 0.02 & -0.04 & -0.05 & -0.05 & -0.07 & -0.05 & 0.00 & 0.05 & 0.07 & 0.14 & 0.01 \\
\hline Scenario $2(\%)$ & 0.00 & 0.01 & 0.01 & 0.02 & 0.02 & -0.01 & -0.02 & -0.03 & -0.05 & -0.04 & -0.01 & 0.02 & 0.03 & 0.06 & 0.00 \\
\hline Scenario $3(\%)$ & 0.00 & 0.01 & 0.01 & 0.01 & 0.00 & -0.03 & -0.03 & -0.02 & -0.02 & -0.01 & 0.01 & 0.03 & 0.04 & 0.08 & 0.01 \\
\hline Net Export & & & & & & & & 000 Bales & & & & & & & \\
\hline Baseline & 11569.71 & 12012.94 & 12308.14 & 12514.99 & 12874.97 & 13158.22 & 13588.23 & 14152.76 & 14582.30 & 14871.81 & 15155.91 & 15251.71 & 15492.86 & 15953.27 & 13820.56 \\
\hline Scenario 1 (\%) & 0.43 & 0.26 & 0.47 & 0.53 & 0.49 & 0.51 & 0.10 & 0.00 & -0.15 & -0.06 & -0.18 & -0.04 & -0.26 & -0.13 & 0.14 \\
\hline Scenario $2(\%)$ & 0.17 & 0.12 & 0.23 & 0.30 & 0.29 & 0.30 & 0.04 & -0.03 & -0.11 & -0.06 & -0.13 & -0.04 & -0.18 & -0.09 & 0.06 \\
\hline Scenario $3(\%)$ & 0.27 & 0.14 & 0.24 & 0.25 & 0.23 & 0.23 & 0.06 & 0.01 & -0.06 & -0.01 & -0.06 & -0.01 & -0.10 & -0.05 & 0.08 \\
\hline End Stock & & & & & & & & 000 Bales & & & & & & & \\
\hline Baseline & 4092.00 & 4095.43 & 4114.31 & 4136.17 & 4221.34 & 4168.55 & 4111.05 & 4179.71 & 4116.94 & 4059.99 & 3978.34 & 3882.10 & 3769.52 & 3606.20 & 4037.98 \\
\hline Scenario 1 (\%) & -1.23 & -0.88 & -0.98 & -1.33 & -1.11 & -0.95 & 0.30 & 0.45 & 0.36 & -0.03 & 0.57 & 0.05 & 0.68 & 0.24 & -0.27 \\
\hline Scenario $2(\%)$ & -0.47 & -0.40 & -0.54 & -0.78 & -0.67 & -0.58 & 0.23 & 0.35 & 0.25 & 0.02 & 0.40 & 0.05 & 0.46 & 0.17 & -0.11 \\
\hline Scenario $3(\%)$ & -0.75 & -0.49 & -0.47 & -0.60 & -0.49 & -0.42 & 0.11 & 0.16 & 0.14 & -0.03 & 0.21 & 0.00 & 0.27 & 0.07 & -0.16 \\
\hline
\end{tabular}


Table 4. Estimated effects of efficient Bt cotton refuge policy compliance in India on the world cotton markets.

\begin{tabular}{|c|c|c|c|c|c|c|c|c|c|c|c|c|c|c|c|}
\hline Parameter & $2012 / 2013$ & $2013 / 2014$ & $2014 / 2015$ & $2015 / 2016$ & $2016 / 2017$ & $2017 / 2018$ & $2018 / 2019$ & $2019 / 2020$ & $2020 / 2021$ & $2021 / 2022$ & $2022 / 2023$ & $2023 / 2024$ & $2024 / 2025$ & $2025 / 2026$ & Avg. \\
\hline A-Index & & & & & & & & \$/Bale & & & & & & & \\
\hline Baseline & 93.26 & 90.95 & 90.84 & 93.08 & 93.80 & 94.12 & 94.19 & 94.45 & 96.48 & 96.29 & 97.43 & 98.29 & 102.16 & 104.89 & 95.73 \\
\hline Scenario $1(\%)$ & 2.71 & 1.57 & 2.01 & 2.80 & 2.28 & 2.01 & -0.98 & -0.97 & -0.77 & 0.17 & -1.47 & 0.06 & -1.68 & -0.20 & 0.54 \\
\hline Scenario $2(\%)$ & 1.04 & 0.74 & 1.13 & 1.66 & 1.37 & 1.21 & -0.72 & -0.77 & -0.53 & 0.02 & -1.03 & 0.00 & -1.12 & -0.15 & 0.20 \\
\hline Scenario $3(\%)$ & 1.66 & 0.86 & 0.95 & 1.26 & 1.01 & 0.88 & -0.36 & -0.33 & -0.30 & 0.11 & -0.55 & 0.06 & -0.67 & -0.06 & 0.32 \\
\hline Area & & & & & & & & 000Acres & & & & & & & \\
\hline Baseline & 85300.79 & 83472.69 & 83104.56 & 84474.07 & 85877.64 & 87826.65 & 88593.82 & 89388.31 & 90017.00 & 90935.60 & 91634.47 & 93587.23 & 94188.46 & 94788.31 & 88799.26 \\
\hline Scenario $1(\%)$ & 0.00 & 0.24 & 0.29 & 0.42 & 0.62 & 0.74 & 0.85 & 0.58 & 0.41 & 0.29 & 0.32 & 0.07 & 0.11 & -0.16 & 0.34 \\
\hline Scenario $2(\%)$ & 0.00 & 0.09 & 0.12 & 0.20 & 0.33 & 0.41 & 0.48 & 0.30 & 0.18 & 0.11 & 0.12 & -0.04 & -0.01 & -0.18 & 0.15 \\
\hline Scenario $3(\%)$ & 0.00 & 0.15 & 0.17 & 0.22 & 0.31 & 0.36 & 0.40 & 0.29 & 0.22 & 0.17 & 0.18 & 0.08 & 0.10 & -0.01 & 0.19 \\
\hline Production & & & & & & & & 000Bales & & & & & & & \\
\hline Baseline & 120605.30 & 120927.88 & 122311.45 & 125578.19 & 127996.65 & 130512.48 & 133042.25 & 135854.90 & 137922.23 & 141335.58 & 143190.21 & 146780.31 & 148790.68 & 150282.66 & 134652.20 \\
\hline Scenario $1(\%)$ & -0.32 & -0.14 & -0.22 & -0.32 & -0.27 & -0.28 & -0.01 & -0.08 & -0.08 & -0.14 & 0.03 & -0.12 & 0.07 & -0.09 & -0.14 \\
\hline Scenario $2(\%)$ & -0.12 & -0.07 & -0.12 & -0.18 & -0.15 & -0.16 & 0.02 & -0.02 & -0.03 & -0.07 & 0.05 & -0.06 & 0.07 & -0.03 & -0.06 \\
\hline Scenario $3(\%)$ & -0.20 & -0.07 & -0.10 & -0.15 & -0.13 & -0.13 & -0.02 & -0.05 & -0.05 & -0.08 & 0.00 & -0.06 & 0.01 & -0.05 & -0.08 \\
\hline Mill Use & & & & & & & & 000Bales & & & & & & & \\
\hline Baseline & 115928.42 & 118949.01 & 123157.17 & 125731.44 & 127682.14 & 129530.85 & 132202.64 & 134752.82 & 137822.67 & 140858.31 & 142891.53 & 146528.35 & 148789.98 & 150592.46 & 133958.41 \\
\hline Scenario 1 (\%) & -0.16 & -0.16 & -0.20 & -0.27 & -0.29 & -0.31 & -0.16 & -0.11 & -0.08 & -0.11 & -0.03 & -0.07 & 0.01 & -0.04 & -0.14 \\
\hline Scenario $2(\%)$ & -0.06 & -0.07 & -0.10 & -0.15 & -0.16 & -0.17 & -0.08 & -0.04 & -0.03 & -0.05 & 0.01 & -0.02 & 0.03 & 0.00 & -0.06 \\
\hline Scenario $3(\%)$ & -0.10 & -0.09 & -0.11 & -0.14 & -0.14 & -0.15 & -0.09 & -0.06 & -0.05 & -0.06 & -0.03 & -0.05 & -0.01 & -0.03 & -0.08 \\
\hline Net Trade & & & & & & & & 000Bales & & & & & & & \\
\hline Baseline & 39264.63 & 39439.31 & 40723.83 & 41353.28 & 43015.40 & 45038.72 & 46203.04 & 47837.11 & 47995.14 & 49374.03 & 48869.12 & 50095.06 & 50603.24 & 51190.85 & 45785.91 \\
\hline Scenario 1 (\%) & -0.48 & -0.61 & -0.74 & -0.99 & -1.08 & -1.10 & -0.70 & -0.40 & -0.25 & -0.27 & -0.06 & -0.05 & 0.14 & 0.16 & -0.46 \\
\hline Scenario $2(\%)$ & -0.19 & -0.26 & -0.36 & -0.53 & -0.59 & -0.61 & -0.37 & -0.17 & -0.08 & -0.10 & 0.04 & 0.03 & 0.15 & 0.16 & -0.21 \\
\hline Scenario $3(\%)$ & -0.30 & -0.35 & -0.39 & -0.49 & -0.52 & -0.52 & -0.35 & -0.22 & -0.16 & -0.16 & -0.07 & -0.06 & 0.02 & 0.03 & -0.25 \\
\hline
\end{tabular}

The estimated effects of refuge requirements on the world cotton market under baseline, and under three alternate policy scenarios are presented and compared in Table 4 . The top set of numbers represents the world cotton price (A-Index) under the baseline scenario, as well as the projected world price under the policy scenarios. The world cotton price ( $A$ index) is expected to increase by
$0.54,0.20$ and $0.32 \%$ for refuge requirements under 15-year, under 10-year, and under EPA mandate, respectively. Higher refuge requirements would decrease the world cotton production, which would push the cotton prices up. Although the area under cotton cultivation would increase in the future, the total production would decline because of relatively lower overall cotton yield resulted from planting refuges. A lower cotton production would pull down mill use and net cotton trade in the world.

Thus higher refuge requirements would decrease world cotton production and trade, and would increase world cotton prices. In the U.S., however, the net export of cotton would increase because of relatively lower export competition from India, 


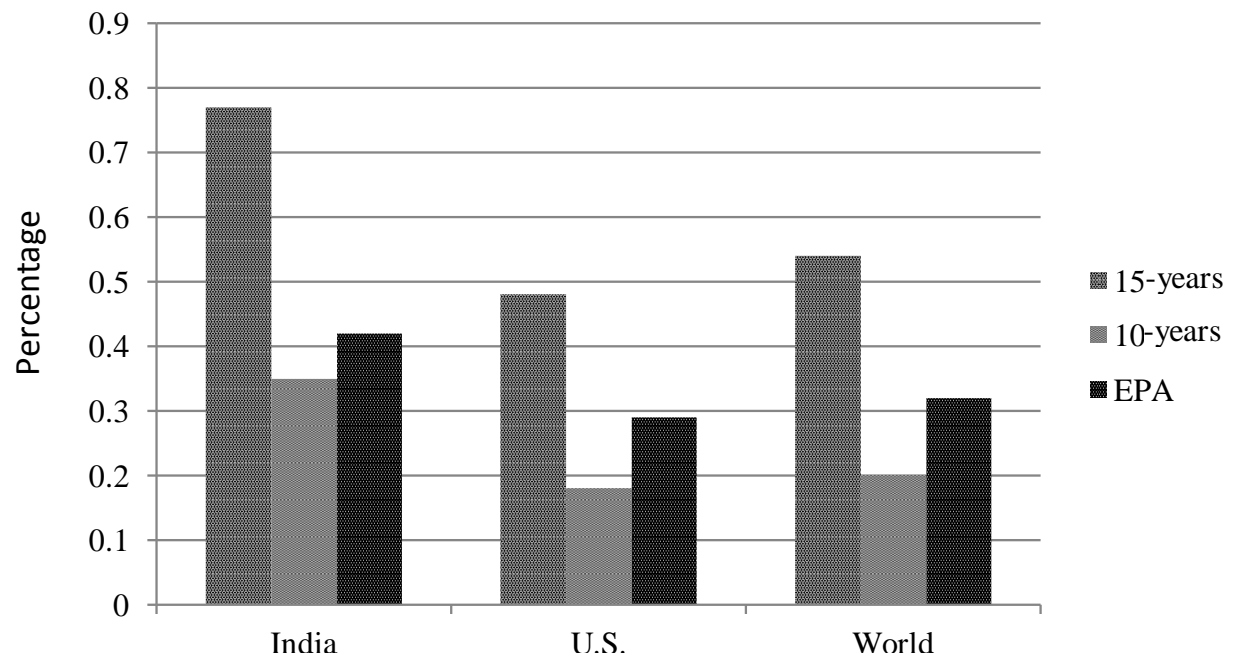

Figure 3. Average price effects of refuge requirements on world cotton markets.

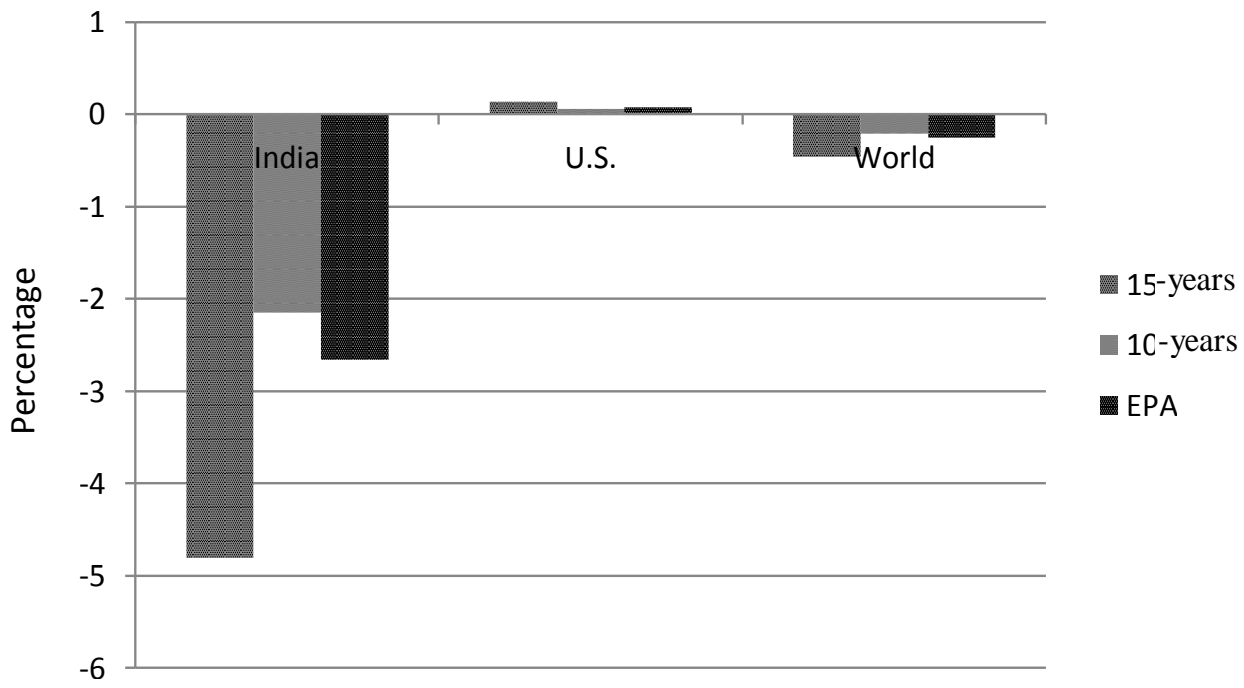

Figure 4. Average trade effects of refuge requirements on world cotton markets.

which stems from a decrease in cotton supply in India resulted from planting refuges. Although the magnitudes of trade and price effects on world markets look dwarf, the impact could sum up to a significant number at an aggregate level given the fact that India occupies $33 \%$ of total cotton area and contributes $23 \%$ to total cotton production in the world.

\section{SUMMARY AND CONCLUSIONS}

The study evaluates the potential impacts of refuge requirements for $\mathrm{Bt}$ cotton in India on world cotton markets by using a partial equilibrium world fiber model. The regional cotton yield models in the Indian fiber model were estimated using proportionate area under $\mathrm{Bt}$ cotton as an exogenous factor in the model. The Indian fiber model is then connected to an existing WFM to conduct baseline and scenarios projections. Three scenarios were considered, which includes optimal refuge requirements under 10-year and 15-year planning period; and refuge requirements under EPA mandate.

Simulation results reveal that cotton refuge requirements in India have potential to affect the domestic market as well as world cotton markets; the magnitude of impact is lower, however. World cotton trade is expected to decrease, and world prices of cotton are expected to rise under higher refuge requirements. In the U.S., however, the net export of cotton is likely to increase because of a decrease in cotton production 
and exports in India resulted from planting refuges. Although the percentage trade and price effects on world cotton markets look smaller, the impact could sum to be a larger amount at an aggregate level given the fact that Indian farmers cultivate about one-third of total cotton area and contributes about one-fourth to total cotton production in the world.

Comparisons of impacts under the three scenarios reveal that magnitudes of impacts depend on length of planning horizon or, in other words, replacement rate of insecticidal $\mathrm{Bt}$ technology. If an existing insecticidal technology is expected to be replaced by a new insecticidal technology early then there are lower refuge requirements and lower negative impacts, and vice versa. Technology replacement rate further depends on time spent in R\&D and regulation to commercialize a new insecticidal technology; a significant time is spent on regulatory approval, however. Thus the time spent in $R \& D$ and regulations of an insecticidal crop technology is an important factor contributing indirectly to determine refuge requirements and their impacts on world commodity markets. A decrease in time in R\&D and regulatory affairs of a new insecticidal agricultural technology has implications for refuge requirements and the world commodity markets.

\section{ACKNOWLEDGEMENT}

The authors thank Dr. Anwar Naseem (McGill University) for providing useful comments on the manuscript.

Abbreviations: EPA, Environmental Protection Agency; USDA, United States Department of Agriculture; WFA, World fiber model; MFA, multi-fiber arrangement; ROW, rest of the World; TRQ, tariff rate quota; WTO, World Trade Organization.

\section{REFERENCES}

Anderson KE, Valenzuela E, Jackson LA (2008). Recent and prospective adoption of genetically modified cotton: A global computable general equilibrium analysis of economic impacts. Econ. Dev. Cultural Change 56:265-296.

Bennett RM, Ismael Y, Kambhampati U, Morse S (2004). Economic Impact of genetically modified cotton in India. Agric. Biol. Forum 7:96100.

Bennett RM, Kambhampati U, Morse S, Ismael Y (2006). Farm-Level economic performance of genetically modified cotton in Maharashtra, India. Rev. Agric. Econ. 28:59-71.

Brookes G, Barfoot P (2007). Global impact of biotech crops: socioeconomic and environmental effects, 1996-2006. Agric. Biol. Forum 11:21-38.

Brookes G, Yu TH, Tokgoz S, Elobeid A (2010). The Production and price impact of biotech corn, canola, and soybean crops. Agric. Biol. Forum 13:25-52.

Choudhary B, Gaur K (2010). Bt Cotton in India: A country profile. ISAAA Series of Biotech Crop Profiles. ISAAA: Ithaca, New York.

Chaudhary J (2005). The future of Indian cotton supply and demand: Implications for the U.S. cotton industry. Ph.D. dissertation, Texas
Tech University, Lubbock, TX

Chaudhary J, Mohanty S, Misra S, Pan S (2008). The effects of MFA quota elimination on Indian fiber markets. Appl. Econ. 40:1083-1099.

Elbehri A, Macdonald S (2004). Estimating the impact of transgenic Bt cotton on West and Central Africa: A general equilibrium approach. World Dev. 32:2049-2064.

Environmental Protection Agency (EPA), Internet site: http://www.epa.gov/oppfead1/cb/csb_page/updates/2007/bollgardcotton.htm (Accessed June, 2010).

Falck Zepeda JB, Traxler G, Nelson RG (2000). Rent creation and distribution from biotechnology innovations: The case of $\mathrm{Bt}$ cotton and herbicide tolerant soybeans in 1997. Agribusiness 16:21-32.

Frisvold GB, Reeves JM (2007). Economy-wide impacts of Bt cotton. Paper presented at Beltwide Cotton Conferences, New Orleans, Lousiana.

Frisvold GB, Reeves JM, Tronstad R (2006). Bt Cotton adoption in the United States and China: International trade and welfare effects. Agric. Biol. Forum 9:69-78.

Frisvold GB, Reeves JM (2008). The costs and benefits of refuge requirements: The case of Bt cotton. Ecol. Econ. 65:87-97.

Huang J, Hu R, Fan C, Pray CE, Rozelle S (2002). Bt cotton benefits, costs, and impacts in China. Agric. Biol. Forum 5:153-166.

Hurley TM, Babcock BA, Hellmich RL (2001). Bt corn and insect resistance: an economic assessment of refuges. J. Agric. Resour. Econ. 26:176-194.

Indiastat.com, Revealing India Statistically. Internet site: www.indiastat.com (Accessed August, 2008)

James C (2009). Global status of commercialized biotech/GM crops: 2009. ISAAA Brief No.41. ISAAA: Ithaca, New York.

Landes M, MacDonald S, Singh SK, Vollrath T (2005). Growth prospects for India's cotton and textile industries. Outlook Report CWS-05D-01, United States Department of AgricultureEconomic Research Service, Washington, DC

Livingston MJ, Carlson GA, Fackler PL (2004). Managing resistance evolution in two pests to two toxins with refuge. Am. J. Agric. Econ. 86:1-13.

National Cotton Council, Internet site: http://www.cotton.org (Accessed June, 2009).

Pan S, Mohanty S, Welch M, Ethridge D, Fadiga M (2007). Effects of Chinese currency revaluation on world fiber markets. Contemporary Econ. Policy 25:185-205

Pan S, Mohanty S (2004). Technical documentation of world fiber model. Cotton Economics Research Institute, Texas Tech University, Lubbock, TX.

Pekaric-Falak I, Meilke K, Huff K (2001). The trade effects of Bt Corn. Canadian Agri-Food Trade Research Network (CATRN) paper.

Purcell JP, Perlak FJ (2004). Global impact of insect-resistant (Bt) cotton. Agric. Biol. Forum 7:27-30.

Qaim M (2003). Bt Cotton in India: Field Trial Results and Economic projections. World Dev. 31:2115-27.

Qiao F, Wilen J, Huang J, Rozelle S (2009). Dynamically optimal strategies for managing the joint resistance of pests to Bt toxin and conventional pesticides in a developing country. Eur. Rev. Agric. Econ. 36:253-279.

Qiao F, Huang J, Rozelle S, Wilen J (2010). Natural refuge crops, buildup of resistance, and zero-refuge strategy for Bt cotton in China. Sci. China Life Sci. 53:1227-1238.

Singla R, Johnson PN, Misra SK (2012). Examination of regional-level efficient refuge requirements for $\mathrm{Bt}$ cotton in India. Agric. Biol. Forum 15:303-314.

Shelton AM, Tang JD, Roush RT, Metz TD, Earle ED (2000). Field tests on managing resistance to Bt-engineered plants. Nat. Biotechnol. 18:339-342.

United States Department of Agriculture- Foreign Agricultural Service, Internet site: http://www.fas.usda.gov (Accessed June, 2009.

United States Department of Agriculture- National Agriculture Statistics Service, Internet site: http://usda01.library.cornell.edu/usda/nass/Acre//2010s/2012/Acre06-29-2012.pdf (Accessed July, 2012)

Yorobe JM, Quicoy CB (2006). Economic impact of Bt corn in the Philippines. Philippine Agricultural Scientist 89:258-267 


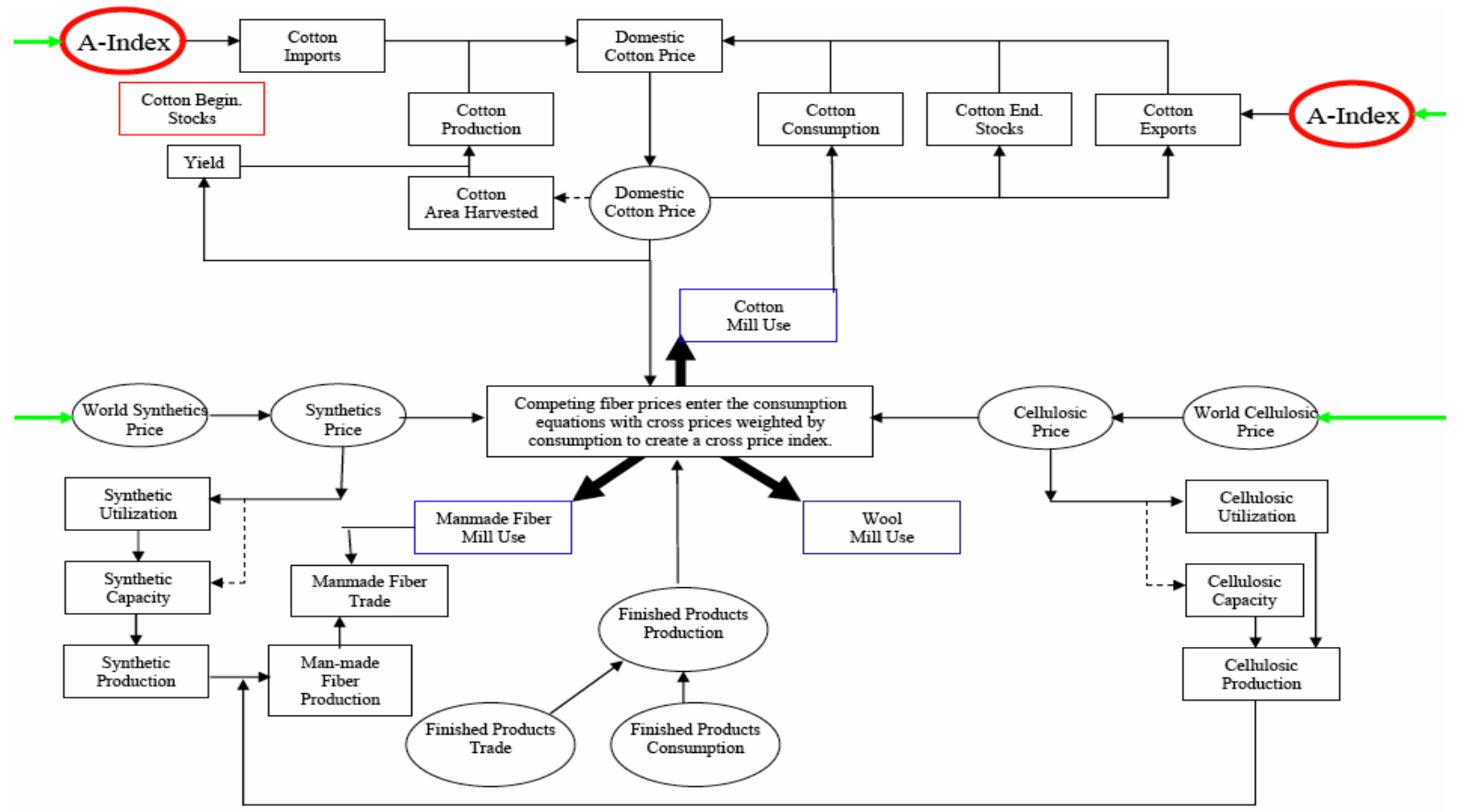

Figure A1. Representative country model.

\section{APPENDIX A}

\section{World fiber model}

The empirical world fiber model is a partial equilibrium structural econometric model developed by Pan and Mohanty (2004) at Cotton Economics Research Institute (CERI), Texas Tech University. The model includes supply, demand and market equilibrium for the cotton and man-made fibers for the U.S., India, China, and 21 other major cotton producing and consuming countries. A representative country model is presented in Figure $\mathrm{A} 1$.

Cotton production in each country and region defined in the model is derived from behavioural equations of area and yield. For geographically large cotton-producing nations such as the United States, China and India, cotton production is estimated in a regional framework to capture regional differences in climate, water availability, and other natural resources that influence crop planting decisions in different parts of each country. The manmade fiber production is derived from estimates of manmade fiber production capacity and utilization rates.

The textile sector in the model is used to determine the mill use of each fiber (cotton, manmade fiber, and wool). It is estimated using a two-step process. In the first step, total fiber demand (cotton, wool, and manmade) is calculated by summing fiber demand in apparel, home furnishing, floor covering, and other industrial sectors. In the second step, total fiber production is divided among cotton, manmade, and wool fibers based on the relative price of each as well as other non-price factors.
Two major applications of world fiber model are presented in Pan et al. (2007) and Chaudhary et al. (2008). While Pan et al. (2007) analyzed the effects of Chinese currency revaluation on world fiber markets, Chaudhary et al. (2008), on the other hand, examined the effects of MFA quota elimination on Indian and world fiber markets. Full explanation of the world fiber model is documented in Pan and Mohanty (2004).

The world fiber model uses data from various sources. Macroeconomic variables for India such as gross domestic product (GDP), population, exchange rate, GDP deflator and the average spot price of crude oil were obtained from International Financial Statistics published by the IMF. Cotton A-index price, US 1.5 denier polyester price, and US farm price sheer wool were collected from Cotton and Wool Yearbook of Economic Research Service, United States Department of Agriculture (ERS, USDA). Prices of polyester staple fibre and cotton fibre, and cotton tariff/duty in India were obtained from Foreign Agricultural Service, USDA and the Textile Commissioner's Office, Government of India (GOI). Minimum support price for cotton and competing crops were obtained from Ministry of Agriculture, India. The textile price index was gathered from the Handbook of Industrial Policy and Statistics 2001, India; at the same time, wholesale price index for food was obtained from the Handbook of Statistics on Indian Economy, 2001 on CD-ROM. Both indices were originally available on $1970 / 1971$ and 1981/1982 base years, which were converted to1993/1994 base year for consistency. The textile price index for the year 1982 to 1984 was missing 
and had to be interpolated. The producer price for cotton and competing crops was obtained from the database of Food and Agricultural Organization (FAO). The consumer price index was gathered from the Ministry of Finance, GOI. Total fibre consumption, total cotton consumption and total man-made fibre consumption were obtained from the FAS/USDA, and the Textile Commissioner's Office, GOI. Wool and other fibre consumption were calculated by subtracting cotton and man-made from total fibre consumption. Similarly, man-made fibre capacity, utilization and man-made fibre production were also collected from the same sources. Data for cotton supply and demand were obtained from the FAS/USDA. The database consists of cotton area, yield, production, imports, exports, ending stocks and total domestic consumption. 